University of Rhode Island

DigitalCommons@URI

Open Access Master's Theses

2000

\title{
THE WATERSHED TRAIL: MELVILLE TO THE GLEN, A GREENWAY MASTER PLAN FOR THE TOWN OF PORTSMOUTH
}

Deidra J. Storti

University of Rhode Island

Follow this and additional works at: https://digitalcommons.uri.edu/theses

\section{Recommended Citation}

Storti, Deidra J., "THE WATERSHED TRAIL: MELVILLE TO THE GLEN, A GREENWAY MASTER PLAN FOR THE TOWN OF PORTSMOUTH" (2000). Open Access Master's Theses. Paper 420.

https://digitalcommons.uri.edu/theses/420

This Thesis is brought to you for free and open access by DigitalCommons@URI. It has been accepted for inclusion in Open Access Master's Theses by an authorized administrator of DigitalCommons@URI. For more information, please contact digitalcommons-group@uri.edu. 
THE WATERSHED TRAIL: MELVILLE TO THE GLEN A GREENWAY MASTER PLAN FOR THE TOWN OF PORTSMOUTH

By

Deirdra J. Storti

A RESEARCH PROJECT SUBMITTED IN PARTIAL FULFILLMENT OF THE REQUIREMENTS FOR THE DEGREE OF MASTER OF COMMUNITY PLANNING

UNIVERSITY OF RHODE ISLAND

2000 
THE WATERSHED TRAIL: MELVILLE TO THE GLEN A GREENWAY MASTER PLAN FOR THE TOWN OF PORTSMOUTH

Research Project

of

Deirdra J. Storti

Major Professor Wal H. Fem h.

Acknowledged:

Director

iv 


\section{The Watershed Trail: Melville to The Glen}

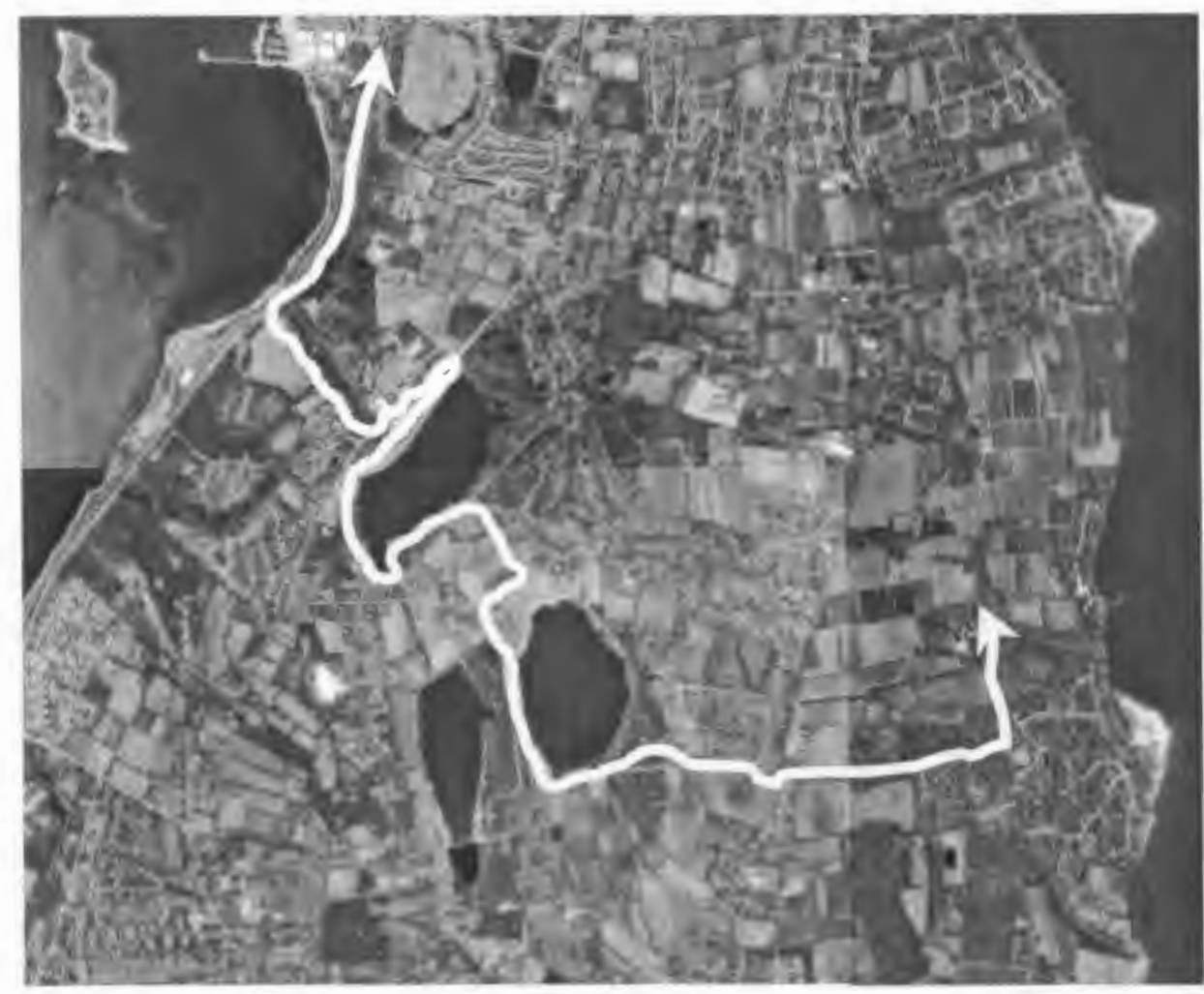

\section{"To make a greenway is to make a community."}

Charles Little, author of Greenways for America 
The Greenway Master Plan is a guide for developing a multi-user trail in the town of Portsmouth, Rhode Island. This report provides a comprehensive approach to implementing a trail from Melville to The Glen, called The Watershed Trail. While it focuses on integrating important aspects of the natural and human environment for one segment of trail, the report could be used to direct the community in developing an island-wide system of various types of publicly accessible trails. The goal of developing the trail is multi-purposed. First, islanders have expressed a desire to develop off-road pathways that link their homes, shopping, employment and recreation destinations by bicycle or walking. Still others want more bridle paths and in-line skating trails. Secondly, islanders want to manage development by directing growth in appropriate areas and have considered greenway development to be a partial solution.

Several forms of data collection were used and analyzed to identify alternatives for trail development. First, Geographical Information Systems (GIS) mapping was analyzed to identify the most appropriate corridor. Considerations were given to existing conservation lands, unconserved environmental resources, and important sites and destinations ${ }^{1}$. Next, the entire trail corridor was walked and field notes were recorded of the existing conditions. Photography and orthophotography provided 
additional information about the resources on the landscape. Finally, a Greenway Master Plan map was produced using land use information from GIS and other graphics to illustrate the opportunities and constraints to trail development. After analyzing this information, alternatives were chosen and final conclusions were made. 


\section{ACKNOWLEDGEMENTS}

Special thanks are given to Dr. Howard Foster and Dr. Farhad Atash from the University of Rhode Island Community Planning Program and Jennifer McCann from the University of Rhode Island Coastal Resources Center/ RI Sea Grant who provided guidance in the successful development of this project and who encouraged an original approach in creating the Greenway Master Plan. It is hoped that members of the Aquidneck Island Partnership, Aquidneck Island Land Trust and Town of Portsmouth who originated the greenway concept will find the plan instrumental in implementing this project. 


\section{CONTENTS}

ABSTRACT

ACKNOWLEDGEMENTS

I. INTRODUCTION 1

Vision of an Island-wide Trail System $\quad 2$

Purpose 3

Multi-Use Trail 5

Multi-Purpose Trail 6

II. INVENTORY OF RESOURCES 10

$\begin{array}{ll}\text { Trail Generators } & 12\end{array}$

Property Ownership 14

III. Master Plan 16

Public Participation and Support 16

Locations and Components of Greenways 17

Accessibility 19

IV. DESIGN GUIDELINES 23

V. Management of THE Trail 25

Seasonal and Nightrime Use $\quad 25$

Maintenance $\quad 26$

VI. RECOMMENDATIONS FOR LONG-TERM GOALS 27

$\begin{array}{ll}\text { Institutionalize Non-motorized Travel } & 27\end{array}$

VII. IMPLEMENTATION 30

VIII. AN ISLAND-WIDE SYSTEM OF TRAILS 32

Proposed Phasing and Timeline $\quad 32$

IX. FUNDING 34

Potential Funding Sources and Technical Assistance 35

Funding Descriptions $\quad 36$

X. Resources 40

Web Resources about Trails 40

$\begin{array}{ll}\text { Publications } & 41\end{array}$

XI. END NOTES 43

XII. APPENDIX $\quad 45$

Appendix A. Trail Inventory Matrix 46

Appendix B. Werlands Permitting Process Checklist 47

Appendix C. Selected Property Ownership Information 48

Appendix D. Recreational Trails Program Brochure 49

Appendix E. 50+ Fun Ways to Fund Your Trail 52

Appendix F. TEA-21 Fact Sheet 53 


\section{LIST OF FIGURES}

00

Figure 1. Trail Generators 14

$\begin{array}{ll}\text { Figure 2. Components of a Trail System } & 18\end{array}$

Figure 3. Recommended Dimensions and Surfacing for Trail 24

Figure 4. Proposed Phasing and Timeline 33

Figure 5. Greenway Master Plan Map_ Pocket 


\section{INTRODUCTION}

Situated on the north portion of Aquidneck Island in Rhode Island, Portsmouth is home to about 17,000 people. The town supports many recreation areas, including Melville campground, The Glen, Sandy Point Beach, several marinas, ball fields, playgrounds and golf courses. These places contribute to residents quality of life, however each is developed separately and without recognition to the regional pattern of development. There are many things Aquidneck Island could do to make its landscape survive the pressures of unguided development. By limiting auto traffic, light rail could help to alleviate the need for more roads. An inter-modal transportation facility could encourage transit-oriented development, the kind of development that supports pedestrian networks and mixed-uses along with common open spaces that are easily accessible. In addition, building a trail system is another way of promoting quality of life on the island. It is recommended that a system of trails be designed to connect major hubs of activity to smaller sites and destinations.

Having a Greenway Master Plan ${ }^{1}$ in place for an Aquidneck Island trail system will ultimately help save time and money since the needs, issues, goals and options are already addressed. A plan also assists in securing funding, solicits feedback from state

\footnotetext{
1 Greenway and trail are used synonymously within the report. For purposes of this report, both mean the
} linkages of various parcels of land or casements that are connected by a designated right-of-way. 
and local government officials, solicits public support, serves as part of comprehensive plans and serves as a blueprint for later work.

The proposed Watershed Trail is the focus of the report and can serve as a model for implementing future trail segments. Beginning at Melville (just North of the Burma Road Bike Path), the trail extends south of Raytheon, through the watershed ponds and connects to Sandy Point Beach and The Glen. It is a 7-mile trail that connects the west side of the island with the east side. The trail would meet the needs of a wide range of users.

\section{VISION OF AN ISLAND-WIDE TRAIL SYSTEM}

The Aquidneck Island Partnership recently published book, Aquidneck Island: Our Shared Vision, which explains islanders desire to use off-road means of travel to get from one destination to another. Islanders identified their favorite places and being able to use off-road trails that connect with their businesses, employment centers, shopping areas, open spaces, farmland and historic places. Several quotes refer to this goal, such as "Link open space areas so that individuals may walk or ride their bikes from one end of the island to the other"; "Active farmland, recreational areas and the coastline would be linked by conservation corridors- greenways. The pattern of open space would buffer and frame appropriate areas for growth" "; connect bike paths and sidewalks to allow residents alternative means of commuting to work. Greenways 
will also serve to preserve wildlife habitats on the island by developing preserved corridors of continuous land.

The greenway concept originated over ten years ago with the Aquidneck Island Land Trust and supporters. With the recent pressure of development, islanders are becoming increasingly concerned about the loss of critical open spaces. Unmanaged development has already fragmented open spaces, thus restricting public access, separating wildlife corridors and eliminating beautiful landscapes. Natural areas, recreation sites, cultural and historic resources as well as urban areas could be linked by paved and natural trails. Islanders needs will not be entirely met unless there is an aggressive effort to reserve these areas for the purposes of recreation and off-road transportation, rather than isolated areas of inaccessible open space.

\section{PURPOSE}

The overall purpose of developing a network of trails and bikeways on the island is to protect its cultural and natural resources for present and future generations while providing off-road travel for those who use the trails as a way to get from one destination to another.

The Florida Greenways Commission developed a statewide initiative to link greenways. Regarding the justification of choosing trail corridors, the plan adheres to 
a sound methodology and public process, stating, "That doesn't mean the state should forge connections for connections' sake. Nor does it mean that the focus of conservation land acquisition should shift from protecting large, functioning ecological preserves to protecting greenways. Greenways is not a connect-the-dots concept applied without justifiable ecological or human need" ${ }^{3}$ Fortunately, the Aquidneck Island Partnership has already begun soliciting support for trail development. This support will only be useful if trail planning turns into trail creation in the foreseeable future.

The trail is a way to provide for the needs of the community by serving as a new form of urban and suburban open space. Open space is being lost to unmanaged development, causing fragmented pieces of privately owned open space. Watershed land is threatened by urban encroachment, thus the drinking water supply and quality is affected. Public access is denied to certain areas because of private development or destination barriers (such as busy roads). Travel options are limited due to a lack of alternative modes of transportation and unsafe conditions on existing road network. Wildlife habitat corridors are disturbed by the lack of a continuous corridor of greenspace.

A greenway has benefits for every community, but a greenway would be especially beneficial for Aquidneck Island because of its uniqueness as an island and the fact that 
it has specific boundaries. Through greenway development, the community can assure preservation of land, guide development to certain locations, increase property values, serve the recreational needs of multi-user groups, gain a tourist treasure, and support an intangible value to the education of its children.

\section{Multi-Use Trail}

The proposed trail system would allow the public to access a continuous corridor of attainable points of interest and view sheds by all non-motorized forms of travel.

\section{Biking}

Seasonally, tourist travel floods the road system, while trying to reach their destinations, whether it be the beaches, downtown Newport or historical sites. This travel puts an increasing demand on the capacity of the roads. Biking is an alternative for commuters who live and work on the island. Bike paths that connect major residential areas to employment centers could alleviate road traffic during the season. The Watershed Trail will not meet the demands for off-road commuting travel since its origin and destination does not, however other segments of the island-wide trail system can be may meet the off-road commuting needs of islanders that live and work in Portsmouth It is encouraged that the island-wide trail system consider the importance of linking future trails from and to highly populated destinations. During the off-season, the whether may not permit biking as a reasonable alternative. However, road travel is diminished at this time due to fewer visitors. The natural 
trails will be more conducive to mountain biking whereas the paved surfaces will provide for excellent road biking.

\section{Horseback Riding}

There is a substantial constituency of equestrians on the island. Many have already expressed an interest in increasing bridle areas. Equestrians are restricted from many parts of the island, including Burma Road and some beaches. A trail around the ponds will be a safe, off-road location for horseback riding.

\section{$\underline{\text { Hiking }}$}

Hikers can pack a picnic and hike along the trail, while stopping at the many peaceful sites along the way.

\section{Multi-Purpose Trail}

The trail is envisioned to provide environmental, social and economic benefits for islanders. The following list includes benefits that could result from an island-wide network of trails. ${ }^{4}$

\section{Transportation Option}

A greenway provides the environment for non-polluting sources of travel, such as biking, hiking and horseback riding. It also serves as an off-road path to various destinations. An island-wide network of trails that connect to high density residences, shopping and business districts could lead to the reduction of road congestion due to less dependence on automobile and an increase in the amount of walking and biking 
trips and inter-modal travel. Nearby employees could use the trail to get to work or take a ride or hike at lunchtime. Tourists could use the trail to explore the island rather than using their car.

\section{$\underline{\text { Economic Development }}$}

The trail implementers could use on-island consultants for design, construction and maintenance of the trail. Income could be collected from shared utility leases. If designed effectively, neighboring real estate value could increase. The trail could be a tourism promoter, connecting various tourist destinations and could help to preserve active farmland. As noted by the Rhode Island Department of Environmental Management, "High quality agricultural soils are distributed throughout the state, however the majority of commercially productive agriculture occurs in Washington and Newport counties."

\section{$\underline{\text { Recreation }}$}

Finding interesting, uncrowded, linear recreation places is rare. A trail would give families a safe place to recreate and would provide a health and fitness alternative for nearby employment centers. The Newport Hospital's Path To Health program may be enthusiastic over coordinating the development of trails.

\section{Planning tool}

Trails can be used as a buffer between competing land uses. A cross-island trail can build a sense of accomplishment, unity and respect between neighboring communities. 


\section{$\underline{\text { Educational }}$}

Creating awareness and appreciation of natural resources and ecosystems can be accomplished through trail systems. For instance, trails can be areas for study in science and history classes. Teachers can encourage field trips and teach about the development and importance of the reservoirs, explore the different habitats of birds or the geology or plant life in the corridor.

\section{Cultural}

The trail connects areas of historic significance and increases awareness of the history in the area.

\section{Wildlife Corridor}

Human users of the trail must remember that because the site surrounds ponds and wooded areas, many geese, deer and other animals use the trail as their living space.

\section{Environmental Protection}

Creates a 'green' corridor to preserve sensitive land, such as wetlands helps to preserve habitat corridors, storm water management, preservation of vegetation, and open space. The Melville to Glen trail is important for preserving valuable watershed land and increasing the awareness of the island's drinking water supply

\section{Quality of Life}

Trails also generate intangibles that are valued by its users. 


\section{Local community plans and ordinances}

The planned trail system meets the objectives of widespread community input as expressed in the Aquidneck Island Land Conservation Strategy, Aquidneck Island: Our Shared Vision and local comprehensive plans. 


\section{INVENTORY OF RESOURCES}

The basis of the inventory was from the Geographical Information Systems (GIS) mapping that Mary Hutchinson produced for the Aquidneck Island Partnership. The maps presented several critical and important lands that should be preserved within the Watershed Trail corridor for environmental protection and cultural resource reasons. Serious consideration was given to the mapping that showed existing conservation lands, unconserved environmental resources, and important sites and destinations.

In collecting the inventory, field notes and pictures were taken of the planned corridor. A Trail Inventory Matrix is shown in Appendix A. The Conservation Funds', Greenways book also provides a detailed inventory checklist (refer to p.28). In addition, land use information from GIS was used and a final Master Plan map incorporates an analysis of the inventory, including opportunities and constraints.

The Watershed Trail is located in a corridor that is topographically flat, which makes it ideal for a trail corridor. The primary concern is the fact that it passes through the buffer areas of the island's three main reservoirs, Lawton Valley, St. Mary's and Sisson Ponds. Mitigation can be taken to ensure adequate protection of the watershed, while providing a trail resource for its community. Two of those mitigation measures will 
be to develop the corridor as a natural trail, meaning an unpaved surface with minimal intrusion on wetland areas and the other is to manage the trail so that only certain users are allowed and maintenance is frequent and monitored.

Apart from conservation reasons, the Watershed Trail was chosen because it links major hubs of activity, sites and points of interest on the west side (Melville) of Aquidneck Island with the east side (The Glen). The following are other points of interest in proximity to the trail.

1) Melville Nature Preserve and Campground (4 miles of trail)

2) Glen Recreational Area

3) Reservoirs

4) Green Valley Country Club

5) Sandy Point Beach

6) Prescott Farm (windmill)

In helping to develop hundreds of trails across the country, the National Park Service states, "A well-designed system of urban linear trails creates recreation as well as travel opportunities that are more easily accessible to large numbers of people. In addition, they can link isolated park fragments, turning a disorganized system of open space into an integrated, multi-purpose recreation system." 
In order to determine the best location for the Watershed Trail and future trails, several types of resources must be analyzed. The Watershed Trail has many natural, environmental and historic features that can be asset and a challenge to trail development.

Another step in setting the location of a trail is to determine the projected users and where they either live or work. It is projected that these users would be best served by the Watershed Trail. Other users include long-term visitors, day trip tourists, urban residents who may want to explore the more rural parts of Aquidneck Island and school children.

\section{TRAIL GENERATORS}

Demographics can determine possible users of the trail based on where they live and work. Aquidneck Island holds a population of approximately 64,544 , according to the 1990 US Census. The Town of Portsmouth includes 16,857 of the total population and has steadily increased since 1960. Portsmouth includes 15,238 acres and has the "most remaining growth potential" than the City of Newport and Town of Middletown, according to a 1990 build-out report. ${ }^{7}$ Development potential for the mainland could increase the number of housing units by 6,721 . 
Also, approximately 80 percent of the total number of workers (8590) that lived in Portsmouth were employed on Aquidneck Island. Approximately 28 percent of all workers worked in Portsmouth. ${ }^{8}$ Even if employees do not live on the island, they still may become important users of the trail and should be considered. Figure 1. illustrates those users who currently live, work or recreation within walking distance of the proposed trail. 
Figure 1. Trail Generators

\begin{tabular}{|l|c|}
\hline Trail Generators & West \\
\hline Melville Marina employees and customers & \\
\hline Melville Campground & \\
\hline Raytheon employees & \\
\hline Bay View Apartments residents & \\
\hline US Navy civilians and personnel & \\
\hline Union Street residents & \\
\hline Green Valley Country Club & \\
\hline Oakland Farms residents & \\
\hline Sandy Point Lane and Wapping Road residents & \\
\hline Pennfield School & \\
\hline Sandy Point Beach & \\
\hline Elmhurst School & \\
\hline Sandy Point Stables & \\
\hline The Glen Park, Glen Manor & \\
\hline
\end{tabular}

\section{PROPERTY OWNERSHIP}

Land within the proposed trail corridor must either be purchased or protected

by an easement. Private property owners must be approached with all the facts available for them in making an informed decision in terms of how the selling of the land or easement will affect their property rights. Incentives to selling, future property value and trail management will be key issues that the negotiator must present.

Much of the trail traverses large parcels that are fortunately open space and rural land. The nature of the land may become an advantage to acquiring 
easement rights. The Aquidneck Island Land Trust owns property within this corridor, making development of a trail on Sandy Point Lane easier. Appendix C. identifies 1999 ownership information of property that the trail traverses and also indicates the features of each property that must be given due consideration during trail construction. 


\section{MASTeR Plan}

Greenways are delicate systems of natural links in the landscape that must serve a

clearly articulated purpose. According to a successful statewide greenways program in Florida, choosing the location of greenways must be a justifiable action. Locations that are chosen without much knowledge of the land that is being preserved will ultimately fail.

In 1999, Aquidneck Islanders and several state and local leaders and nonprofit representatives joined together in an effort to identify the land in most need for remediation or acquisition. A report entitled Aquidneck Island: Land Conservation Strategy was developed to guide the island communities in making land use decisions that would help in preserving the most critical land. The Greenway Master Plan includes these areas and provides more details on preserving trail corridors from Melville to the Glen. The master plan map shows the preferred trail routes, existing conditions and opportunities for development, given the goals of the community and the needs of the environment.

\section{Public PARTICIPATION AND SUPPORT}

Supporters will ensure that the greenway trail becomes a reality. Without adequate support, it will be difficult for a small group of people to convince the town that trail 
creation is a true benefit. Potential supporters may include the island historical societies, Aquidneck Island Partnership members including Newport County Chamber of Commerce, Aquidneck Island Land Trust and Newport County Board of Realtors, Newport County Convention and Visitors Bureau, the Newport HospitalPath to Health program, and employment centers, such as Raytheon, the U.S. Navy and educational institutions.

\section{LOCATIONS AND COMPONENTS OF GREENWAYS}

The Florida Statewide Greenway Plan identifies a successful technique for choosing locations of greenways. It recommends determining where the hubs, sites and links are within the proposed greenway. When these areas are mapped, they should connect together to form an interesting route that would begin and end from a major origin and destination point and then include interesting sites along the way. Figure 2. was developed after identifying the primary origin and destination points of the trail users. 
Figure 2. Components of a Trail System

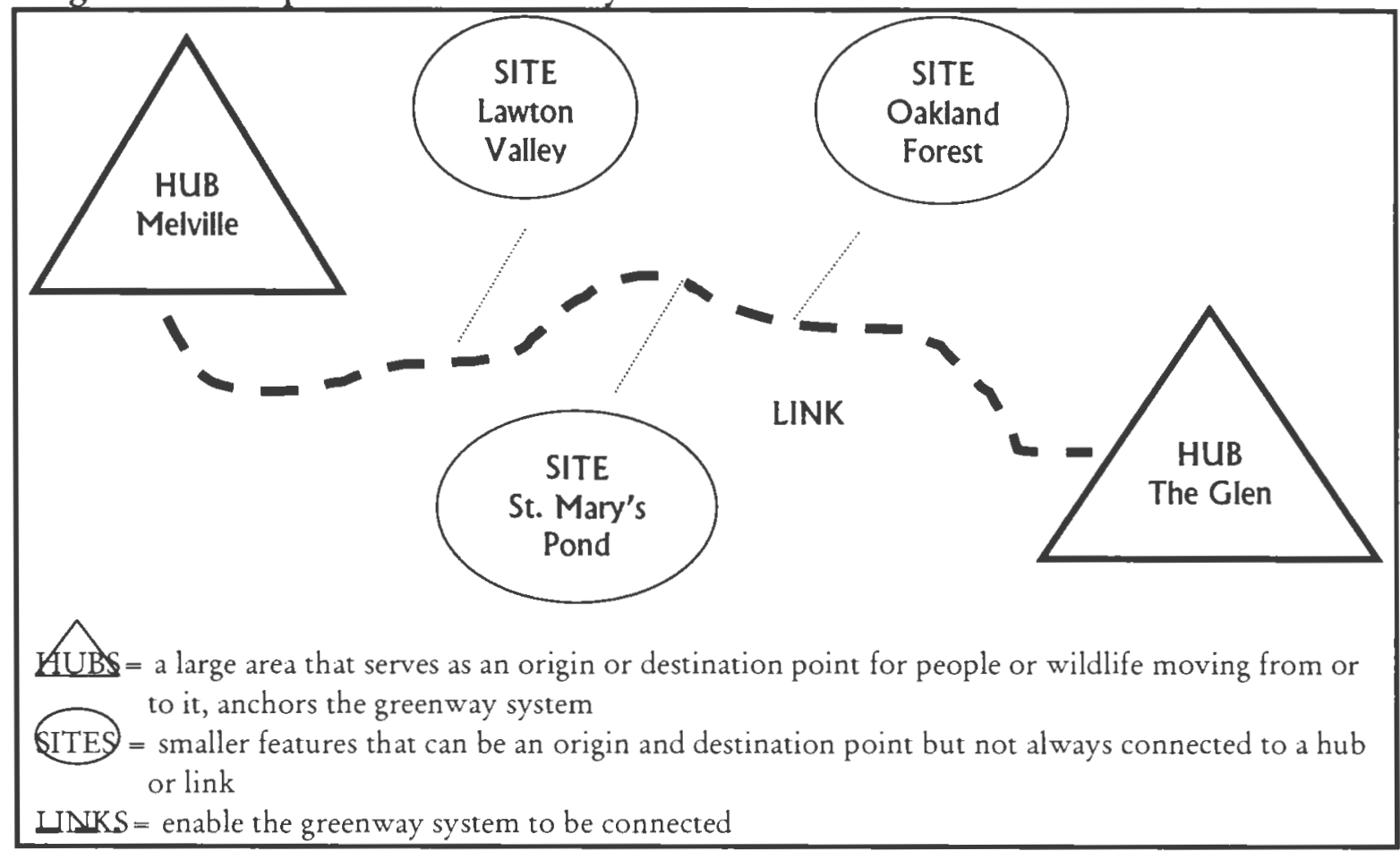

Source: Greenways: A Guide to Planning, Design and Development, Charles A. Flink ${ }^{9}$ 


\section{ACCESSIBILITY}

Accessing the trail is a primary concern that involves safety considerations and wellplanned design of entranceways and corridors. Corridors have been identified to illustrate the characteristic differences between geographical sections of trail. Two types of corridors are differentiated, greenways and urban corridors. The difference is based on whether or not they travel along side or parallel to a roadway. The Greenway Master Plan map identifies the existing conditions of each trail corridor and describes the preferred route based on assessing all reasonable alternatives. The following discusses design considerations and accessibility to entranceways and explains the characteristics of greenway and urban corridors.

\section{$\underline{\text { Entranceways }}$}

Entranceways are points of public access to the trail corridor. The Greenway Plan identifies four primary entranceways (Burma Road, West Main Road, Sandy Point Lane, and Glen Park) and three secondary entranceways (two at Union Street and Glen Farm Road). Primary entranceways are major access areas that can accommodate higher levels of traffic from trail users. Primary entranceways are also areas for potential trail-related facilities, such as restrooms, benches, kiosks, and other 'trail furniture' as described later. Secondary entranceways are those areas that cannot support high levels of traffic from trail users, due to adjacent land uses, such as suburban edges or environmental features. The character of the greenway should be 
expressed at all entranceways. Character can be expressed through a tailored landscape design and by adding directional kiosks, benches and interpretive signs describing the significance of the trail corridor (i.e. the formation and importance of the reservoirs).

\section{Facilities and Trail Furniture at Entranceways}

Parking lots and bicycle racks are important facilities that are required for successful trail access. Parking areas and bike racks would serve the highest level of trail users at the Burma Road entrance, Lawton Valley entrance, Sandy Point Beach entrance and Glen Park entrance. Restrooms should also be located in these high use origins and destinations. The Union Street entrance is not appropriate for such facilities because of its close proximity to housing and limited available public space.

Each entrance to the trail must be regulated to prohibit inappropriate uses of the trail. For instance, even though the trail may be wide enough to support snowmobiles, there are other reasons for restricting such a use. These restrictions must be efficiently posted in strategic locations in order to fully aware the potential user. Trail entrances are areas where users begin their trail excursion and therefore are appropriate places for postings. Strategically placed at trail entrances, small wooden kiosks can be built to post updated messages about trail use. Connections to points of interest should be clearly marked by posting trailheads and proper signage along trail entranceways. Bollards can be used at trail entrances to obstruct access to the trail by motorized 
vehicles. Painting or marking the bollards with a bright color will increase their visibility to users. Spacing between bollards should be wide enough to leave room for wheelchairs, bicycles and horses. Other trail entrance furniture includes trash receptacles, bag dispensers for dog waste and trash, user surveys, informative stands, water bubblers and benches.

\section{$\underline{\text { Urban Corridors }}$}

Urban corridors are transportation routes that can provide easy access to the trail and create awareness among passersby. Consequently, these corridors can also prevent the convenient and safe mobility of greenway users, including wildlife.

There are four urban corridors within the planned Watershed Trail; Burma Road, West Main Road, Union Street and Sandy Point Lane. Safety should be the foremost concern in these areas, since they share space on the road or are adjacent to motorized road travel.

\section{Greenway Corridors}

Greenway corridors are areas that do not parallel a roadway, but are rather part of a larger 'green' or natural corridor of land. Greenway Corridors provide access to view sheds and environmental and historic features, such as ponds, stonewalls, plants, forests, and wildlife. Geese, deer and other wildlife use such corridors for nesting, 
breeding and feeding and movement. Construction of a trail should minimize impact to the existing habitats.

\section{Suburban Edges}

Adjacent residential development is necessary for successful usage of the corridor for recreation or commuting. Union Street is a primary east-west transportation route connecting East and West Main Road and subsequently holds many residences along its corridor. Private property and public access are issues that must be alleviated during the early planning stages. 


\section{DESIGN GUIDELINES}

Design guidelines should be used to meet the needs of each type of trail user. Figure 3. summarizes the recommended surfacing requirements and dimensions of a multi-use trail as tailored to each specified corridor. Several resources can be used to determine the guidelines, including Universal Access to Outdoor Recreation: A Design Guideline, AASHTO's Guide for Development of New Bicycle Facilities, Design Manual: 1020 Facilities for Nonmotorized Transportation, and Pedestrian Facilities Guidebook. 
Figure 3. Recommended Dimensions and Surfacing for Trail

\begin{tabular}{|c|c|c|c|c|}
\hline $\begin{array}{l}\text { Corridor } \\
\text { Names: }\end{array}$ & Surfacing & $\begin{array}{c}\text { Multi- } \\
\text { Use Two- } \\
\text { Way } \\
\text { Trail } \\
\text { Width }\end{array}$ & $\begin{array}{l}\text { Roadway } \\
\text { Separation }\end{array}$ & $\begin{array}{l}\text { Vertical/ } \\
\text { Lateral } \\
\text { Minimum } \\
\text { Clearance }\end{array}$ \\
\hline \multicolumn{5}{|l|}{ Urban Corridors } \\
\hline $\begin{array}{l}\text { 1. Burma Road } \\
\text { Bike Path }\end{array}$ & $\begin{array}{l}\text { Compacted } \\
\text { crushed } \\
\text { rock }\end{array}$ & $\begin{array}{l}10^{\prime} \\
\text { minimum }\end{array}$ & $\begin{array}{l}5 \text { minimum separation } \\
\text { between road and trail }\end{array}$ & $\begin{array}{l}8 \% 1 \text { ' on each } \\
\text { side of trail, } \\
\text { graded to the } \\
\text { same slope as } \\
\text { trail }\end{array}$ \\
\hline $\begin{array}{l}\text { 3. West Main } \\
\text { Road }\end{array}$ & $\begin{array}{l}\text { Compacted } \\
\text { crushed } \\
\text { rock }\end{array}$ & $\begin{array}{l}10^{\prime} \\
\text { minimum }\end{array}$ & $\begin{array}{l}5 \text { ' minimum separation } \\
\text { between road and trail }\end{array}$ & $\begin{array}{l}\text { NA (good } \\
\text { visibility } \& \\
\text { clearance) } / 1 \text {, }\end{array}$ \\
\hline 5. Union Street & $\begin{array}{l}\text { Paved, } \\
\text { widen } \\
\text { right-of- } \\
\text { way on } \\
\text { south side } \\
\text { of existing } \\
\text { road }\end{array}$ & $\begin{array}{l}4^{\prime} \\
\text { maximum }\end{array}$ & $\begin{array}{l}\text { Minimum separation } \\
\text { cannot be met due to } \\
\text { stonewalls \& narrow } \\
\text { roadway. Use traffic } \\
\text { calming measures, such } \\
\text { as raised \& painted } \\
\text { crosswalks and } \\
\text { textured boundaries. }\end{array}$ & $\begin{array}{l}\text { NA (good } \\
\text { visibility } \& \\
\text { clearance } \\
\text { exists)/ 1' }\end{array}$ \\
\hline $\begin{array}{l}\text { 7. Sandy Point } \\
\text { Lane }\end{array}$ & $\begin{array}{l}\text { Compacted } \\
\text { crushed } \\
\text { rock }\end{array}$ & $\begin{array}{l}10 \\
\text { minimum }\end{array}$ & $\begin{array}{l}\text { 5' minimum } \\
\text { separation/ } 0 \text { ' } \\
\text { minimum on Glen } \\
\text { Farm Road }\end{array}$ & $8 \% 1$ \\
\hline \multicolumn{5}{|c|}{ Greenway Corridors } \\
\hline $\begin{array}{l}\text { 2. Lawton } \\
\text { Valley Stream }\end{array}$ & $\begin{array}{l}\text { Compacted } \\
\text { crushed } \\
\text { rock }\end{array}$ & $\begin{array}{l}10 \\
\text { minimum }\end{array}$ & NA & $\begin{array}{l}8 \% / 2 ' \text { (install } \\
\text { guardrail at } \\
\text { grade) }\end{array}$ \\
\hline $\begin{array}{l}\text { 4. Lawton } \\
\text { Valley } \\
\text { Reservoir }\end{array}$ & $\begin{array}{l}\text { Compacted } \\
\text { crushed } \\
\text { rock }\end{array}$ & $\begin{array}{l}10^{\prime} \\
\text { minimum }\end{array}$ & $\mathrm{NA}$ & $8 \% 1$ \\
\hline $\begin{array}{l}\text { 6. St. Mary's } \\
\text { Pond }\end{array}$ & $\begin{array}{l}\text { Compacted } \\
\text { crushed } \\
\text { rock }\end{array}$ & $\begin{array}{l}10 \\
\text { minimum }\end{array}$ & NA & $8 \% 1^{\prime}$ \\
\hline
\end{tabular}

"Numbers refer to reference areas on the Master Plan map.

Source: Adapted from AASHTO's Guide for Development of New Bicycle Facilities and Pedestrian Facilities Guidebook 


\section{MANAGEMENT OF THE TRAIL}

Since the trail traverses watersheds, special consideration to protection of the area must be taken. Signage and educational brochures can be used along the trail to educate the public and encourage responsible behavior within the corridor.

\section{SEASONAL AND NIGHTTIME USE}

The trail should be open all year round. This way multiple users will be served and year-round, off-road access to their destinations will be maintained. Snow removal on greenway corridors should not be sanctioned. It is costly for the community, could damage the natural terrain and would prevent use of the trail for cross-country skiers and snowshoers. In addition, it is expected the number of users in the off-season will be low since the weather is cold and tourists are infrequent.

The Watershed Trail does not require access to trail destinations after daylight hours, primarily because the trail is within a suburban and rural area. Since the trail is within close proximity to housing and serves as a corridor for wildlife, lighting and access should not be provided. Therefore, nighttime use should be restricted. Signage and brochures could be used to clearly advertise the rule in addition to posting enforcement notices. 


\section{MAINTENANCE}

A volunteer user group could raise funds through the town to maintain the trail during the year, including trash pick-up, footbridge repair and signage upkeep. Proper maintenance and frequent inspection could save money in the long term.

Furthermore, minimal maintenance will be needed if effective signage and promotional brochures are used to educate users on trail etiquette. Funds could also be used to provide trash receptacles at entrances and exits or bag dispensers to encourage a 'carry-in, carry-out' system.

A maintenance program should be clearly defined so that it eliminates confusion over responsibilities. The program would include requirements for upkeep of the trail surface and facilities, funding sources, designation of a maintenance team, and a timetable of responsibilities and tasks. 


\section{RECOMMENDATIONS FOR LONG-TERM GOALS}

\section{INSTITUTIONALIZE NON-MOTORIZED TRAVEL}

As an overall effort to garner widespread support of an island-wide bikeway and trail system, organizers should promote the legitimacy of bicycling and walking. ${ }^{10}$ Institutionalization is the process of integrating bicycle and pedestrian considerations into state and local transportation planning, design, and operations. There must be at least minimal public and political support for bicycling and walking within a community in order for efforts to become serious. Some ways to institutionalize nonmotorized travel are:

- Police on bikes- 200 police department's patrol on bikes. There is a general trend towards "community policing" on bikes. Statistics in some locations, such as Seattle, show that police on bikes is effective crime busting technique.

- Corporate and Agency commuting-Corporations and local police donate unclaimed bikes to employees if they use them to travel to work a certain number of days per year.

- Events and Promotions raise awareness- walk-a-thons/ bike rides with politicians

- Drivers Educations classes

- Safety and education 
- Statistics and surveys- how many in the community use and would use bikes/ walking

- Get bicycle and pedestrian considerations institutionalized within local and state transportation planning, design and operations. 3 elements are required- hire a coordinator, obtain political support and involve citizens

- Get the greenways plan reviewed by the state- (DOT, RIDEM, Statewide Planning). Find out who is supportive and works "on the inside". Someone who will work with local governments and nonprofits.

- Create a relationship with state funding decision-makers.

- Begin TEA-21 application for FY 2001. Work closely and early with RIDOT.

- Use Master Plan Map as marketing tool for trail support.

- Promote an increased use of bicycling and encourage planners and engineers to accommodate bicycle and pedestrian needs in designing transportation facilities for urban and suburban areas.

- The island should hire a full-time trail coordinator, if serious about developing an island-wide system of trails. Knowledge about land acquisition, environmental constraints, meeting the needs of various constituencies, applying for funding. The trail system has been supported by town officials, residents, community groups and state representatives

- Include trail recommendations in the Portsmouth Community Comprehensive Plan revision. Approved by the town in September of 1992, the plan states the 
need for bicycle paths as an alternative mode of transportation as well as for recreation purposes. The trail can meet many of the outlined objectives of the plan. ${ }^{11}$ 


\section{IMPLEMENTATION}

Next steps after developing the greenway plan are to organize creation of the trail. The following steps illustrate the primary stages and responsibilities involved in trail creation.

Hire or commit a full-time Trail Coordinator to continually seek funding, support and technical assistance so that trail creation becomes a reality.

- Solicit public support for trail construction and negotiate with landowners so as to ensure that their needs are met.

- Contact state agencies, such as RI Department of Environmental Management, RI Department of Transportation and the Coastal Resources Management Council, regarding requirements in trail construction and funding opportunities.

Write grant applications, solicit donations and begin a Trail Fund. Begin trail design process by hiring a landscape architect to assess wetlands delineations and identify plant-life.

Produce engineering drawings for proposed trail.

Hold public meetings and gather public feedback regarding trail design and construction. 
Acquire necessary permits. (See Appendix B. Wetlands Permitting Process Checklist)

Hire a local construction company and ensure protection of sensitive areas and preservation of the trail by implementing remediation measures, such as easements, footbridges, or pedestrian crosswalks for these locations.

Organize volunteer marketing, maintenance and management teams who will take responsibility for making the trail a success. 
Proposed Phasing And Timeline

As the professional planning field professes, linking conservation lands to create an interconnected network of open space should be pushed beyond municipal boundaries. ${ }^{12}$ Fortunately, Aquidneck Island has shared commitments from several political leaders and community groups. The Aquidneck Island Land Trust has raised funds to develop the next phase of the island-wide trail from The Glen to Braman Lane. Figure 4. is a list of proposed phases and timeline for completion. It is assumed that planning for the subsequent phase begins at the design and implementation stage of the present phase. Each trail segment could be named to correspond to the characteristics or physical features of its natural and built landscape (i.e. the Watershed Trail or the Vineyard Route). 
Figure 4. Proposed Phasing and Timeline

\begin{tabular}{|c|c|c|c|c|}
\hline Phase & Geographic Area & $\begin{array}{l}\text { Greenway } \\
(\mathrm{G}) \\
\text { Urban (U) } \\
\end{array}$ & $\begin{array}{l}\text { Length } \\
\text { ( } \sim \text { Miles })\end{array}$ & $\begin{array}{l}\text { Year of } \\
\text { Completion }\end{array}$ \\
\hline $\begin{array}{l}\text { ONE } \\
\text { "The Glen Trail" }\end{array}$ & $\begin{array}{l}\text { The Glen to Braman } \\
\text { Lane }\end{array}$ & G & 2 & 2001 \\
\hline \begin{tabular}{|l} 
TWO \\
"The Watershed \\
Trail" \\
\end{tabular} & Melville to The Glen & $\bar{G}$ & $\overline{7}$ & 2002 \\
\hline THREE & \begin{tabular}{|l|} 
Braman Lane to \\
Sachuest Point
\end{tabular} & G & 4 & 2002 \\
\hline FOUR & $\begin{array}{l}\text { Sachuest Point to Cliff } \\
\text { Walk at Almy Pond } \\
\end{array}$ & $\mathrm{U}$ & 5 & 2003 \\
\hline \begin{tabular}{|l|} 
FIVE \\
"West Shore Bike \\
Path" \\
\end{tabular} & $\begin{array}{l}\text { Burma Road to Mount } \\
\text { Hope Bridge }\end{array}$ & $\mathrm{U}$ & 3 & 2003 \\
\hline SIX & $\begin{array}{l}\text { Cliff Walk at Almy } \\
\text { Pond to Fort Adams }\end{array}$ & $\mathrm{U}$ & 3 & 2004 \\
\hline SEVEN & $\begin{array}{l}\text { Fort Adams to Thames } \\
\text { Street }\end{array}$ & $\bar{U}$ & 4 & 2005 \\
\hline EIGHT & $\begin{array}{l}\text { Thames Street to } \\
\text { Middletown Town } \\
\text { Center }\end{array}$ & $\mathrm{U}$ & 2 & 2006 \\
\hline NINE & \begin{tabular}{|l} 
Middletown Town \\
Center to Burma Road
\end{tabular} & $\overline{\mathrm{U}}$ & 2 & 2006 \\
\hline TEN & $\begin{array}{l}\text { Mt Hope Bridge to } \\
\text { Middletown Town } \\
\text { Center }\end{array}$ & $\mathrm{U}$ & 8 & 2007 \\
\hline TOTAL & & $\begin{array}{l}\mathrm{U}= \\
\mathrm{G}=\end{array}$ & $\begin{array}{l}27 \\
\frac{13}{40} \\
\end{array}$ & \\
\hline
\end{tabular}




\section{FUNDING}

Volunteers can serve as committed resources and some are able to provide expert advise on various stages of the project. However, for much of the trail design and construction, consultants should be contacted. Cost estimates should be sought regarding services for wetlands permitting, trail design and development, including footbridges and trail posts, advertising, such as publishing user guides and web site information, and management and ongoing maintenance of trail. The estimates will dive trail organizers a fairly rough estimate of how much funds they should expect to raise. Estimates are also handy to justify where money can be saved and how it should be spent.

Numerous public and private funding sources exist for greenway development. Typically, raising more than $20-50$ percent of funds from the private sector is rare (Greenways). Fundraisers should expect to diversify their funding sources even though Aquidneck Island has strong public support for greenway development and has been lucky in having strong support from private interests. ${ }^{13}$ Obtaining local financial support can serve as matching funds and supplemental funding to private support (see Appendix E for additional funding ideas). ${ }^{1+}$ 


\section{Potential Funding Sources and Technical Assistance}

\section{Federal and State}

US. Fish and Wildlife

Transportation Equity Act of the Twenty-First Century

National Park Service

State Corrections Agency- Products, like signs and picnic tables

Bureau of Land Management

Environmental Protection Agency

Department of Housing and Urban Development- Community Development Block Grants

US. Forest Service

Soil Conservation Service

Rhode Island Department of Transportation

Rhode Island Department of Environmental Management

Local, Private and Nonprofit

\begin{tabular}{|c|c|}
\hline Public & Private and Nonprofit \\
\hline Town Budget & Foundations and Charitable Organizations \\
\hline Newport Water Department & \multirow{2}{*}{$\begin{array}{l}\text { Local Businesses: Raytheon, Melville Marine } \\
\text { Industries, Kmart, BJ's, Ames, Stop and Shop, } \\
\text { Christmas Tree Shop, Clement's Market }\end{array}$} \\
\hline School District- if educational benefit & \\
\hline Norman Bird Sanctuary-technical assistance & \multirow{3}{*}{$\begin{array}{l}\text { Kodak American Greenways Awards } \\
\text { Program- the grant amount ranges between } \\
\$ 500 \text { and } \$ 1000 \text { each year and is given to } \\
\text { organizations that wish to plan or design a } \\
\text { greenway. Contact: American Greenways, } \\
\text { The Conservation Fund, } 1800 \text { North Kent St. } \\
\text { Suite } 1120 \text {, Arlington, VA, } 22209 \text {, (703) } 525- \\
6300 \text { (www.conservationfund.org) }\end{array}$} \\
\hline Aquidneck Island Land Trust & \\
\hline $\begin{array}{l}\text { Parks and Recreation Department (City of } \\
\text { Newport) }\end{array}$ & \\
\hline $\begin{array}{l}\text { Local revenues can be raised from property } \\
\text { taxes or bond issues (Portsmouth has a sales } \\
\text { tax on Real Estate transfers) }\end{array}$ & \multirow{2}{*}{$\begin{array}{l}\text { Trails and Greenways Clearinghouse- } \\
\text { technical assistance can be obtained through } \\
\text { the clearinghouse- a partnership of the Rails- } \\
\text { to-Trails Conservancy and The Conservation } \\
\text { Fund. Contact: Betsy Goodrich, Manager, } \\
\text { Rails-to-Trails Conservancy, 1100 } 17^{\text {th }} \text { Street, } \\
\text { NW, 10 }{ }^{\text {th }} \text { Floor, Washington, DC, 20036, } \\
\text { 877-GRNWAYS, (202)-974-5123, Fax: (202) } \\
\text { 331-9680, greenways@transact.org, } \\
\text { (www.trailsandgreenways.org) }\end{array}$} \\
\hline \multirow[t]{3}{*}{ Impact fees } & \\
\hline & The Trust for Public Land \\
\hline & \\
\hline
\end{tabular}




\section{FUNDING DESCRIPTIONS}

\section{TEA-21 (Transportation Equity Act for the Twenty-First Century)}

In recognizing the need to promote funding for various types of transportation alternatives, Congress authorized the Inter-modal Surface Transportation Efficiency Act of 1991. Reauthorized under TEA-21 in 1998, the Recreation Trails Program (see Appendix D) has seen a $\$ 10$ million increase in trail funds each year. Rhode Island has received $\$ 526,694$ for the fiscal year 2000 and will receive an apportionment of the $\$ 50$ million in the years FY 2001, 2002, and 2003. ${ }^{2}$ The increase is an attempt to provide communities with the necessary funding for safe and convenient transportation alternatives, while encouraging off-road travel. Trail, bicycle and pedestrian facilities are also eligible for funding under several other TEA-21 funding categories, such as Transportation Enhancements, Congestion Mitigation and Air Quality and Scenic Byways Program. ${ }^{15}$

Rhode Island's, Trails Advisory Committee awards the federal grants to communities planning a trail or greenway. A Trail Improvement Grant Application is required for review of funding eligibility. The Rhode Island Department of Transportation should be contacted regarding TEA-21 FY 2001 funding (see Appendix F. for additional information about TEA-21). 


\section{State Open Space Bond 2000}

Governor Almond is proposing a $\$ 50$ million bond for the November ballot in order to acquire 35,000 acres of open spaces, parks, wildlife habitats and other land by 2010 . The bond will be used to leverage matching funds and other funding sources, resulting in a total of $\$ 100$ million or more for open space protection over ten years. "The target of 35,000 acres of Open Space was derived in the State Greenspace and Greenways Plan by determining the 'critical geographical areas supporting essential greenspace values' (including forests, agriculture, biodiversity and wildlife, recreation and culture, and water supply) and the extent of both presently developed land and existing protected open space." ${ }^{16}$

\section{Impact Fees}

Growth management techniques can be used to increase the amount of support for greenways. For instance, impact fees, a way for communities to garner funds for the impact that a development has on part of the community, can be assessed through regulated subdivision policies. The policies can require that site improvements or funds be provided for open space and trails. Impact fees are assessments levied on new development to help pay for the construction of off-site improvements that benefit the contributing development. Impact fees are one-time charges usually assessed at the time of development approval. ${ }^{17}$ Impact fees are generally accepted as a way for the 
community to practice its police powers. The Court system has determined that when instituting fees, there must be a rational nexus or reasonable relationship between the fee and the development that is being regulated. The standards include: 1 . the need for new facilities must be created by new development (therefore, a community would not be allowed to charge, unless there is a clear impact), 2. the fee amount must be proportionate to the impact of the new development, and 3. fee revenues must be spent within a reasonable time frame. Impact fee facilities range from: fire/ EMS and police service, libraries, open space and parks, public buildings, roads, schools, solid waster, wastewater, drinking water, storm water.

"In some communities, impact fees are actually considered a pro-growth tool because of their ability to defuse rising no-growth sentiments, ensure facility adequacy and facilitate development approval.", "Unlike many other financing options, impact fees can encourage efficient development patterns as well as raise revenues." ${ }^{18}$ The general concept is that fees are increased in existing areas that lack sufficient public services and lowered in areas that contain adequate services.

Impact fees cannot be attributed to deficiencies caused by previous development. Generally, revenues are spent in the zone or service-area in which new development occurs. Therefore, impact fees for an island-wide system of trails must be carefully considered to ensure their justification. 


\section{Millennium Trails Program}

Millennium Trails is a partnership among the White House Millennium Council, the U.S. Department of Transportation and Rails-to-Trails Conservancy in cooperation with other agencies and organizations. Millennium Trails is a national initiative to recognize, promote and support trails that preserve open spaces, interpret history and culture and enhance recreation and tourism. The East Coast Greenways, a planned trail spanning from Maine to Florida, is one of six nationally recognized, Millennium Trails that has recently been funded. The Rhode Island East Coast Greenways Alliance has been actively working to developing pieces of the trail throughout the state. Aquidneck Island should coordinate with ECGA to ensure future trail connections to the island. ECGA can be contacted at kvotava935@aol.com or contact the Rails-to-Trails Conservancy below.

Millennium Trails

c/o Rails-to-Trails Conservancy 1100 17th Street, NW, 10th Floor Washington, DC 20036
Phone: 1-877-MIL-TRLS (toll-free)

Fax: 202-466-3742

E-mail:miltrails@transact.org

Web site: www.millenniumtrails.org 


\section{RESOURCES}

Web Resources about TRaILS

\begin{tabular}{|c|c|}
\hline Organization & Web Site \\
\hline $\begin{array}{l}\text { American Trails, a national trails advocacy } \\
\text { organization working for the common interests of } \\
\text { all trail users. }\end{array}$ & $\begin{array}{l}\text { www.outdoorlink.com/amtra } \\
\text { ils }\end{array}$ \\
\hline $\begin{array}{l}\text { The Trails and Greenways Clearinghouse provides } \\
\text { technical assistance and information resources on } \\
\text { all aspects of trail and greenway advocacy, } \\
\text { acquisition, development, and management. The } \\
\text { Clearinghouse is a joint project of Rails-to-Trails } \\
\text { Conservancy and The Conservation Fund's } \\
\text { American Greenways Program. }\end{array}$ & www.trailsandgreenways.org \\
\hline Rails-to-Trails Conservancy & www.railtrails.org \\
\hline $\begin{array}{l}\text { The National Transportation Enhancement } \\
\text { Clearinghouse - provides information on the } \\
\text { Transportation Enhancement Program, a funding } \\
\text { source for nonmotorized trails that serve a } \\
\text { transportation function. }\end{array}$ & www.transact.org \\
\hline $\begin{array}{l}\text { The Millennium Trails Program is a national } \\
\text { initiative led by the White House Millennium } \\
\text { Council, USDOT, Rails-to-Trails Conservancy, and } \\
\text { other agencies and organizations who are working } \\
\text { to make trails part of America's legacy for the } \\
\text { future. }\end{array}$ & www.millenniumtrails.org \\
\hline $\begin{array}{l}\text { The } 1999 \text { Recreational Trails Program Awards } \\
\text { from the Coalition for Recreational Trails. }\end{array}$ & $\begin{array}{l}\text { www.nrpa.org/infoctr/ppolic } \\
\text { y/juldatpr.htm }\end{array}$ \\
\hline Rhode Islands state parks and beaches & http://www.riparks.com/listi \\
\hline $\begin{array}{l}\text { Crazyjane Mountain Biking pages lists several trails } \\
\text { in Rhode Island: }\end{array}$ & $\begin{array}{l}\text { http://www pavin.com: } 80 / \mathrm{cli} \\
\text { ents/bzine/rides/trails/states/ } \\
\text { ri.htm }\end{array}$ \\
\hline $\begin{array}{l}\text { New England Mountain Bike Association has a } \\
\text { descriptions of Places to Mountain Bike in Rhode } \\
\text { Island: }\end{array}$ & $\begin{array}{l}\text { http://www.nemba.org/ri/pl } \\
\text { aces.html }\end{array}$ \\
\hline
\end{tabular}


Mountain Club is the local Rhode Island affiliate of the Boston based AMC.

Rhode Island's North South Trail runs 72 miles along the western edge of the state:

The East Bay Bike Path is a 14-mile rail trail between Bristol and Providence:

The East Coast Greenway is a project underway to

link seaboard states with a largely off-road route; information is available for Maine, New

Hampshire, Massachusetts, Rhode Island,

Connecticut, New York, New Jersey,

Pennsylvania, Delaware, and Maryland:

Cape Cod Trails Conference

Cape Cod Pathways, Model Trail

The Massachusetts and Rhode Island Trail Guide

(7th ed.) is published by the Appalachian Mountain

Club; ISBN: 1-878239-39-2:

Federal Highway Administration. Recreational

Trails Program.

Rhode Island Department of Transportation

National Park Service

www.cctrails.org (email:

cctrails@cctrails.org)

http://www.capecodcommiss ion.org/pwayfaq.htm

http://www.gorp.com/atb/n

eweng/G3072.HTM

http://www.fhwa.dot.gov/en vironment/rectrail.htm

Web: www.dot.state.ri.us

www.nps.gov

\section{Publications}

- A Guide to Transportation Enhancements is available from the National Transportation Enhancements Clearinghouse, 1100 17th St., N.W., Washington, DC 20036 (on the web: www.enhancements.org).

- Conflicts on Multiple Use Trails is a synthesis of research on trail conflicts, with 12 principles to minimize trail conflict. To order: send a fax to the FHWA R\&T Report Center, fax \#301-577-1421, and request publication FHWA-PD94-031, Conflicts on Multiple Use Trails. 
- Designing Sidewalks and Trails for Access is a two-part report on pedestrian accessibility. The first part, Review of Existing Guidelines and Practices, (available September 1999) lays out the history and the practices of applying accessibility concepts to sidewalks and pedestrian trails. Part II, a Best Practices Guidebook, will be published in the winter 1999-2000. To order Part I: send a fax to the FHWA R\&T Report Center, fax \#301-577-1421, and request publication FHWA-HEP-99-006, Designing Sidewalks and Trails for Access, Part I, Review of Existing Guidelines and Practices.

- Fuel Used for Off-Road Recreation: A Reassessment of the Fuel Use Model, July 1999, a report for FHWA by the Oak Ridge National Laboratory, provides estimates of the relative amount of off-road recreational fuel use by State. The model developed in this report provides the base for the apportionments under the Recreational Trails Program for FY 2000.

- Universal Access to Outdoor Recreation: A Design Guideline. PLAE, Inc.

- Design Manual: 1020 Facilities for Nonmotorized Transportation, Washington State Department of Transportation 


\section{END NOTES}

'Hutchinson, Mary. 1999. Preferred Preservation Mapping (PPM). Mapping and Planning Services. Prepared for the Aquidneck Island Land Trust.

${ }^{2}$ McCann, J., D. Storti, V. Lee. 1999. Aquidneck Island: Our Shared Vision. Aquidneck Island Partnership. Rhode Island Sea Grant.

${ }^{3}$ Florida Greenways Commission. December 1994. Report to the Governor. Creating a Statewide Greenways System, For People...For Wildlife...For Florida. p.10.

* U.S. Department of Transportation. Federal Highway Administration. The National Bicycling and Walking Study: Transportation Choices for a Changing America. Final Report. Publication No.FHWA-PD-94-023.

${ }^{5}$ Rhode Island Department of Environmental Management. Division of Planning and Development. May 1996. Protecting Our Land Resources: A Land Acquisition and Protection Plan for the Rhode Island Department of Environmental Management. p. 6.

${ }^{6}$ U.S. Department of the Interior. National Park Service. Tools and Strategies, Preserving Open Space: A Guide for New England. No Date.

${ }^{7}$ Aquidneck Island Build-out Analysis. June 1991. IEP, Inc. Prepared for the Newport County Chamber of Commerce, Towns and Middletown and Portsmouth and City of Newport.

81990 Census Data For Transportation Planning. Technical Paper Number 145. January 1994. Division of Planning, RI Department of Administration. p.58.

${ }^{9}$ Flink, Charles. 1993. Greenways: A Guide to Planning, Design and Development. Island Press.

${ }^{10}$ U.S. Department of Transportation. Federal Highway Administration. Case Study No. 21. Integrating Bicycling and Pedestrian Considerations into State and Local Transportation Planning, 
Design, and Operations. National Bicycling and Walking Study. Publication No. FHWA-PD-93-

017. July 1992. Submitted to: FHA. Prepared by: Bicycle Federation of America. p. 35.

"Portsmouth Comprehensive Community Plan. September 1992. Town of Portsmouth, RI.

12 Arendt, Randall G. 1996. Conservation Design for Subdivisions: A Practical Guide to Open Space

Networks. Chapter 6. Open Space Networks. Natural Lands Trust, American Planning

Association, and American Society of Landscape Architects. Island Press.

${ }^{13}$ McCann, J., D. Storti, V. Lee. 1999. Aquidneck Island: Our Shared Vision. Aquidneck Island

Partnership. Rhode Island Sea Grant.

${ }^{1+}$ Rails-to-Trails Conservancy. Local Funding Sources Fact Sheet. Excerpted from Secrets of Successful Rail-Trails: An Acquisition and Organizing Manual for Converting Rails into Trails.

${ }^{15}$ Rails-to-Trails Conservancy. TEA-21 Fact Sheet. January 1999.

${ }^{16}$ Rhode Island Department of Environmental Management. Open Space Bond 2000.

http://www.state.ri.us/dem/openfaq.htm

${ }^{17}$ Nelson and Duncan. Growth Management Principles and Practices. American Planning Association. Planner's Press. Chicago, Ill. 1995. pp.120-23.

${ }^{18}$ Et Al. 
APPENDIX

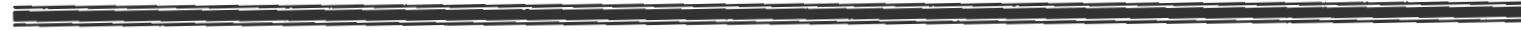


Appendix A: Trail Inventory Matrix

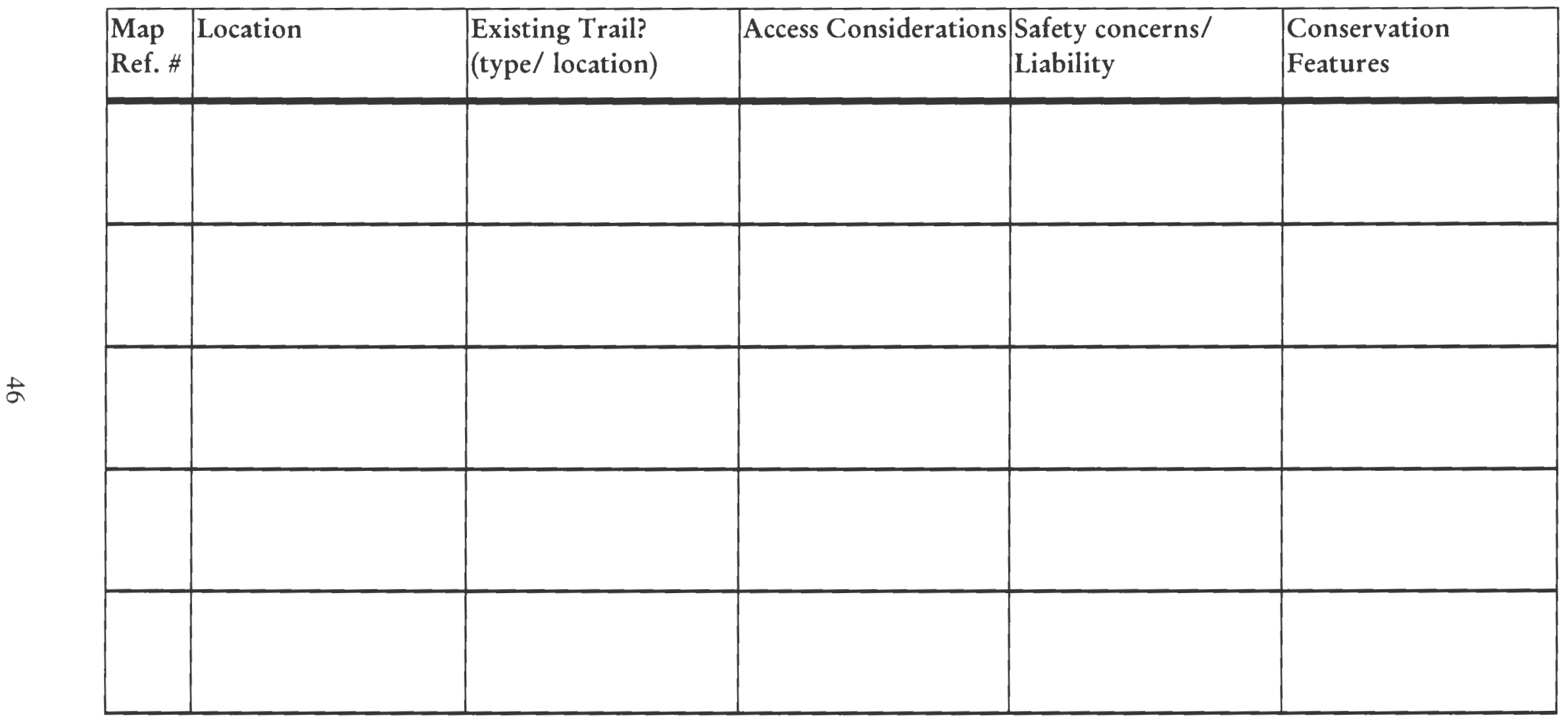


Appendix B. Wetlands Permitting Process Checklist

\begin{tabular}{|c|c|}
\hline Check & Task \\
\hline & Determine who has jurisdiction of the project (DEM or CRMC) \\
\hline & Hire an engineer and biological consultant to flag wetlands and advise \\
\hline & Have DEM verify flagged wetlands and get a preliminary determination \\
\hline & $\begin{array}{l}\text { Applicant begins permitting process. (Submit one application with each } \\
\text { property owner's approval. Applicant has to be the property owner or } \\
\text { owner of easement.) } \\
\text { - Contact property owners regarding approval to submit for permits. }\end{array}$ \\
\hline & $\begin{array}{l}\text { DEM/CRMC must determine the significance of the alteration } \\
\text { Significant alteration (permitting process may take } 8-10 \text { months) } \\
\text { Request for preliminary determination } \\
\text { - after wetlands edges flagged by an engineer, DEM will verify the flags } \\
\text { - an engineering review may take } 60-80 \text { days } \\
\text { Contact: Chuck Horbert at DEM, Wetlands Permitting ( } 222-6820 \times 7402 \text { ) } \\
\text { or from Office of Technical and Customer Assistance }\end{array}$ \\
\hline & Set meeting with DEM- bring design of trail \\
\hline
\end{tabular}


Appendix C. Selected Property Ownership Information

\begin{tabular}{|c|c|c|c|c|c|c|c|}
\hline & Plat/Lot & Location & $\begin{array}{l}\text { Ownership/ } \\
\text { Contact }\end{array}$ & Acres & Assessed Value & Existing Trail? & $\begin{array}{l}\text { Conserv-ation } \\
\text { Features }\end{array}$ \\
\hline \multicolumn{8}{|l|}{ Portsmouth } \\
\hline Oakland Forest & & $\begin{array}{l}\text { Adjacent to } \\
\text { Oakland Farm } \\
\text { development. } \\
\text { West of East } \\
\text { Main Rd }\end{array}$ & $\begin{array}{l}\text { Armory Revival } \\
\text { Company, } \\
\text { Providence }\end{array}$ & 20 & $\$ 1.7$ Million & $\begin{array}{l}\text { Path/ runs north } \\
\text { to south through } \\
\text { forest }\end{array}$ & $\mathrm{Q}, \mathrm{E}, \mathrm{H}, \mathrm{A}, \mathrm{G}, \mathrm{S}$, \\
\hline $\begin{array}{l}\text { Oakland } \\
\text { Meadow }\end{array}$ & & $\begin{array}{l}\text { Adjacent to } \\
\text { Oakland Farm } \\
\text { development. } \\
\text { West of East } \\
\text { Main Rd }\end{array}$ & $\begin{array}{l}\text { Newport Water } \\
\text { Department }\end{array}$ & 16 & $\$ 385,000$ Paid & Yes. & $\begin{array}{l}Q, E, H, G, V, \\
W, S\end{array}$ \\
\hline St. Mary's & $61-3$ & East Main Rd & $\begin{array}{l}\text { St. Mary's } \\
\text { Church }\end{array}$ & 69 & $\$ 359,400$ & & $P, E, H, G$ \\
\hline \multirow[t]{2}{*}{ St. Mary's } & $\begin{array}{l}57-18 / 13- \\
\text { residential }\end{array}$ & 294 Union St & $\begin{array}{l}\text { St. Mary's } \\
\text { Church }\end{array}$ & 17.91 & $\$ 149,400$ & & $P, E, H, G$ \\
\hline & $\begin{array}{l}57-112 / 13- \\
\text { residential }\end{array}$ & Carriage Drive & & & $\$ 55,900$ & & \\
\hline Lawton Valley & $\begin{array}{l}56-14 \\
1-S F R\end{array}$ & $\begin{array}{l}745 \text { Union } 5 t \\
\text { Southern tip of } \\
\text { Lawton Valley } \\
\text { Reservoir }\end{array}$ & Jerry DeLisle & 3.75 & $\$ 235,100$ & & $\mathrm{~A}, \mathrm{~V}, \mathrm{Q}, \mathrm{T}, \mathrm{H}, \mathrm{W}, \mathrm{S}$ \\
\hline
\end{tabular}

\section{Conservation Features (Prepared from Aquidneck Island Land Trust's Project Prospectus)}

$\mathrm{R}=$ River corridor

$\mathrm{T}=$ Tributary Corridor

$Q=$ Water quality or supply land

$\mathrm{L}=$ Lakes, ponds, or springs

$\mathrm{E}=$ Exemplary ecosystem

$\mathrm{H}=$ Wildlife habitat
$A=$ Historic or archeological land

$\mathrm{G}=$ Recreational or greenway land

$\mathrm{V}=$ Scenic vista or view shed

$W=$ Wetlands

$\mathrm{S}=$ Environmentally significant land

$\mathrm{P}=$ Productive agricultural or forest land 


\section{Appendix D.}

Recreational Trails Program Brocbure ${ }^{3}$

What is the Recreational Trails Program?

The U.S. Congress first authorized the Recreational Trails Program in the Intermodal Surface Transportation Efficiency Act of 1991. It was reauthorized in 1998 under the Transportation Equity Act for the 21st Century (TEA-21).

The Recreational Trails Program provides funds to the States to develop and maintain recreational trails and trail-related facilities for both nonmotorized and motorized recreational trail uses. Examples of trail uses include hiking, bicycling, in-line skating, equestrian use, cross-country skiing, snowmobiling, offroad motorcyling, all-terrain vehicle riding, four-wheel driving, or using other off-road motorized vehicles.

\section{Who administers the program?}

The Recreational Trails Program is an assistance program of the U.S. Department of Transportation's Federal Highway Administration (FHWA). Each State administers its own program, usually through a State resource or park agency. Each State develops its own procedures to solicit and select projects for funding. Each State has a State Recreational Trail Advisory Committee to assist with the program. In some States, the committee selects the projects, in others, the committee is advisory only. See the State contact list.

\section{How much money is available?}

Under TEA-21, the Congress authorized the Recreational Trails Program $\$ 30$ million in 1998, $\$ 40$ million in 1999, and $\$ 50$ million annually for 2000, 2001, 2002, and 2003. Previous funding in 1996 and 1997 was $\$ 15$ million each year.

FHWA may use up to $1 \frac{1}{2}$ percent of the funds for program administration and trail related research and technical assistance. The remainder of the funds are distributed to the States. Half of the funds are distributed equally among all States, and half are distributed in proportion to the estimated amount of off-road recreational fuel use in each State-fuel used for off-road recreation by snowmobiles, all-terrain vehicles, off-road motorcycles, and off-road light trucks.

\section{What projects are eligible?}

Recreational Trails Program funds may be used for:

- maintenance and restoration of existing trails;

- development and rehabilitation of trailside and trailhead facilities and trail linkages;

- $\quad$ purchase and lease of trail construction and maintenance equipment;

- construction of new trails (with restrictions for new trails on Federal lands);

- acquisition of easements or property for trails

\footnotetext{
${ }^{3}$ Federal Highway Administration. www.fhwa.dot.gov/environment/rtbroch.htm
} 
- State administrative costs related to this program (limited to 7 percent of a State's funds); and

- operation of educational programs to promote safety and environmental protection related to trails (limited to 5 percent of a State's funds).

States must use 30 percent of their funds for motorized trail uses, 30 percent for nonmotorized trail uses, and 40 percent for diverse trail uses. Diverse motorized projects (such as snowmobile and motorcycle) or diverse nonmotorized projects (such as pedestrian and equestrian) may satisfy two of these categories at the same time. States are encouraged to consider projects that benefit both motorized and nonmotorized users, such as common trailhead facilities. Many States give extra credit in their selection criteria to projects that benefit multiple trail uses.

\section{Which projects are not eligible?}

Recreational Trails Program funds may not be used for:

- property condemnation (eminent domain);

- constructing new trails for motorized use on National Forest or Bureau of Land Management lands unless the project is consistent with resource management plans; or

- facilitating motorized access on otherwise nonmotorized trails.

These funds are intended for recreational trails; they may not be used to improve roads for general passenger vehicle use or to provide shoulders or sidewalks along roads.

A project proposal solely for trail planning would not be eligible (except a State may use its administrative funds for statewide trail planning). However, some project development costs may be allowable if they are a relatively small part of a particular trail maintenanace, facility development, or construction project.

\section{Who can sponsor a project?}

States may make grants to private organizations, or to municipal, county, State, or Federal government agencies. Some States, by policy, do not provide funds to private organizations. Projects may be on public or private land, but projects on private land must provide written assurances of public access.

States are encouraged to use qualified youth conservation or service corps for construction and maintenance of recreational trails under this program.

\section{How does project funding work?}

Project amounts vary by State, but most range in value from $\$ 2,000$ to $\$ 50,000$. Some States set minimum or maximum allowable dollar values.

In general, the maximum Federal share for each project from Recreational Trails Program funds is 80 percent. A Federal agency project sponsor may provide additional Federal funds, provided the total Federal share does not exceed 95 percent. The non-Federal match must come from project sponsors or other fund sources. Funds from any other Federal program may be used for the non-Federal match if the project also is eligible under the other program. States also may allow a programmatic match: if some project sponsors in a State provide more match funds than required, other sponsors in the State may provide less. Some in-kind materials and services may be credited toward the project match. 
Usually, project payment takes place on a reimbursement basis: the project sponsor must incur costs for work actually completed, and then submit vouchers to the State for payment. Reimbursement is not normally permitted for work that takes place prior to project approval. However, working capital advances may be permitted on a case-by-case basis, and some project development costs may be reimbursable.

\section{How do I obtain Recreational Trails Program project funding?}

Each State has its own procedures to solicit and select recreational trails projects for funding. A project sponsor should develop its proposal sufficiently so that the project may move quickly into implementation after project approval.

If you have a trail project proposal, first contact your State to find out the program requirements and criteria for project selection. As a project sponsor, you should:

- Develop a workable project. What are your trail needs? What can you do realistically?

- Get public support for your project. How does your project benefit your community? Are there other potential project sponsors?

- Find other funding sources. The normal Federal share is limited to 80 percent. Some State or local governments may provide some matching funds, but usually the project sponsor has to provide most or all of the match. Consider donations of materials and volunteer labor.

- Consider how to involve youth conservation or service corps in your project.

- Develop a good project design. Consider the project's natural environment. Consider user needs, including use by people with disabilities.

- Consider potential problems:

- Environmental impacts - these must be documented and minimized.

- Permits - you may need to obtain various permits prior to submitting your proposal.

- Possible opposition - some people may oppose your project for various reasons, including concerns about property rights, liability, safety, or historic or environmental impacts.

- Complete the project application.

- If your project is approved, get to work! States may withdraw project approval if a sponsor does not begin work within a reasonable time frame. 
APPENDIX E 


\section{$50^{+}$FUN WAYS TO FUND YOUR TRAIL}

1. lease trail right-of-way for cellular phone towers

2. lease trail right-of-way for other utilities (gas, electric, water, sewer, cable, telephone)

3. charge concession stands a fee to operate on the trail

4. set up a concessions stand

5. rent bicycles and other trail equipment

6. sell posters or art of the trail

7. sell sponsorships of feet/ meters/miles of the trail

8. sell mileage markers

9. sell trail tags with trail logo and donor's name for donors to wear on t-shirts and hats

10. sell planks or bricks

11. sell trees with plaques

12. sell trail amenities (drinking fountains, shelters, benches, etc.)

13. sell special trail products like Rail-Trail Ale

14. create a gift catalogue to sell trail items, including trail feet, amenities, etc.

15. sell memberships in friends of the trail groups

16. ask the railroad or property owner to donate the right-of-way

17. ask sporting goods stores to impose a voluntary surcharge on sales and donate the proceeds to the trail

18. ask bookstores or other businesses to donate a percentage of sales on a given day to the trail

19. at large events, operate a bicycle corral where people can safely store their bicycles and riding gear, charge a fee

20. hold a 'fly-the-trail' event - pilots donate their time and airplanes to fly people over the trail to build membership and support

21. "Blues ' $n$ ' Brews" -- live blues performers at a micro-brewery festival

22. "Chowder Challenge" -- restaurants and hotels donate food and facility

23. hold a dance on the trail event

24. sponsor a poker game along the trail

25. hold a long-distance race, charge an entry fee

26. hold a regatta on the river adjacent to your trail, charge an entry fee

27. establish a farmer's market along the trail, charge vendors a fee

28. charge a fee for groups who use the trail for special events

29. ask your local court to direct non-felons to perform community service work on trails

30. impose fines for violations of trail rules

31. arrange for trips on the trail for officials and potential sponsors -- ask them for donations

32. have an art show -- artists donate their work

33. hold a raffle with donated items from local businesses

34. hold an auction -- sell donated items

35. hold yard sales, bake sales, etc.

36. run an adopt-a-trail program 
37. "Bridge Builder Program" -- individuals and businesses adopt a bridge by helping fund its construction

38. ask the National Guard to help build or maintain your trail

39. ask Army Engineering Battalions for their services

40. ask local unions for donations of services

41. off-track betting mitigation

42. gambling fees for charitable purposes

43. approve a real estate transfer tax for open space and trails

44. establish a "quality-of-life" sales tax

45. earmark lodging taxes or resort taxes

46. check-off box on income tax form

47. motor vehicle title transfer fees

48. sin taxes

49. pass a bond

50. approve a new sales tax

51. lobby for local government appropriations

52. bottle bill fund

53. set up a memorial fund

54. work in partnership with an experienced fund-raising organization, e.g. a local college or university or a local foundation 


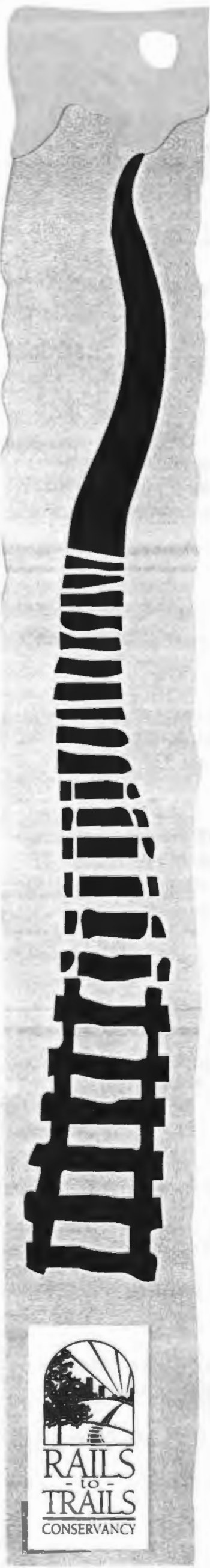

\section{TEA-21}

What is TEA-21 and what does it mean for trails?

In 1991 Congress enacted the Intermodal Surface Transportation Efficiency Act (ISTEA, pronounced "icetea") a six-year bill authorizing a wide range of federal-aid transportation programs In June of 1998 , the Transportation Equity Act for the Twenty-First Century (IEA-21) was enacted to reauthorize many of the revolutionary transportation policies and funding programs begun in ISTEA.

ISTEA has been, and TEA-2l promises to be, a tremendous boon to trail development and bicycle and pedestrian facilities of all kinds. In six years, ISTEA provided over \$1 Billion for multi-use trail development, including more than $\$ 350$ million for rail-trails. TEA-21 will provide federal transportation funding for another six years, from fiscal year 1998-2003. It has the potential to take trail system development to a whole new level.

What are the highlights? Transportation Enhancements program funding levels are up almost 40 percent. The Recreational Trails Program has guaranteed funding of almost $\$ 45$ million per year. Eligibility for trails was retained in all the major programs and even expanded. But the key to remember is that outside the Recreational Trails Program, federal transportation law does not guarantee that money will be spent on trails. Trail projects must compete in various venues with other transportation projects for resources that even though expanded are far short of the nation's dernand for transportation dollars. As in ISTEA, state Departments of Transportation (DOTs) remain the key access point for projects that seek federal transportation dollars for trails, bicycle and pedestrian facilities. State park and natural resource agencies, metropolitan planning organizations (MPOs), and local government remain key partners to include when pursuing development of a local, regional or statewide trail system.

Fifteen sections of the Act refer directly to the bicycling and walking modes of travel. Trail development projects are eligible for funding from at least twelve different programs in TEA-21.

TEA-21 Programs for Trails, Bicycle and Pedestrian Facilities
1) Transportation Enhancements Activities (TE or TEAs)
2) Recreational Trails Program (Rec. Trails)
3) "Core" Surface Transportation Program (STP)
4) Congestion Mitigation \& Air Quality Improvement
Program (CMAQ)
5) Federal Lands Program (FLIP)
6) Scenic Byways Program
7) Highway Safety Program
8) Bridge Program
9) National Highway System
10) Transit Enhancements
11) Transportation \& Community \& System Preservation Pilot Program

Among these twelve programs, the two programs most likely to provide access for trail funding remain the Transportation Enhancements program and Recreational Trails program. For information on acquiring funding for trail projects from the Congestion Mitigation \& Air Quality Improvement Program (CMAQ) or Surface Transportation Program (STP), order Technical Brief \#4: Beyond Enhancements: Making the STP and CMAQ Programs in ISTEA Work for Bicyclists and Pedestrians (See For More Information).

\section{How to Make IEA-21 Work for Your Trail System}

While TEA-2l is a new federal law, the old adage "all politics is local" should govern the trail advocate's basic approach to acquiring TEA-21 funds for trails. Both Transportation Enhancements and Recreational Trails Program funding decisions are made at the state and local levels of government. To be an effective advocate for your trail system under TEA-21, it is essential to understand the basic components of the RTA and TE programs.

\section{THE ENHANCEMENTS PROVISION OF ISTEA}

The Transportation Enhancernents provisions of TEA-2l are a ten percent set-aside found within the Act's Surface Transportation Program (STP). Several of the activities eligible for TE funding have been modified in the new Act. These modifications are shown in bold. 
1) Bicjcle \&r Pedestrian Facilities

2) Acquisition of Scenic Easements \& Scenic/Historic Sites

3) Scenic or Historic Highway Programs (including Visitor and Welcome Centers)

4) Landscaping \& Scenic Beautification

5) Historic Preservation

6) Rehabilitation \&r Operation of Historic Transportation Buildings, Structures or Facilities

7) Preservation of Abandoned Railway Corridors by Converting them to Rail-Trails
8) Control \&r Removal of Outdoor Advertising

9) Archaeological Planning \& Research

10) Mitigation of Water Pollution Due to Highway Runoff and Provision of Wildlife Undercrossings for Protection of Endangered or Threatened Species

\section{New TEAs}

11) Provision of Safety and Educational Activities for Pedestrians and Bicyclists

12) Establishment of Transportation Museums

While trails are most commonly funded from categories (1) and (7), they also can be included in combination with the other activities in more comprehensive Enhancement projects.

How much money is available?

Approximately $\$ 3.6$ billion nationally in federal dollars/funding will be made available for Transportation Enhancements activities over the life of TEA-21 (see Rails-to-Trails Conservancy's website, www railtrails.org, for apportionment funding tables organized by' state). Although states may have restrictions, federal law allows TE funds to be used for many costs associated with trail development, including planning, engineering and design, land acquisition and construction.

\section{How can my trail group access Enhancement funds?}

The first step is usually submission of a formal application to the state Department of Transportation's Transportation Enhancements Program. In most states, the project spohsor submitting this application must be either a local government or a state agency: Some states, however, allow non-governmental organizations, such as a trail group or land trust, to apply if they obtain some level of government endorsement prior to submitting their application.

Contrary to popular understanding, the TE program is not a grant program. Rather, it operates as a reimbursement program. Most states require that a minimum of 20 percent of the project's total cost be provided by the project sponsor. The remaining 80 percent is paid out of Federal Highway Trust funds.

\section{Where can I get more information?}

Contact the National Transportation Enhancements Clearinghouse (NTEC) for a 2-page profile of your state's TE program, including the name and phone number of the state DOT Transportation Enhancements Program Manager. NTEC also can provide a list of other TE projects funded in your state as well as a wide range of general and technical documents about the Transportation Enhancements program. See For More Information, below. NTEC can provide a current list of State Trail and Recreational Trail Program Coordinators.

\section{THE RECREATIONAL TRAILS PROGRAM}

Under TEA-2l the Recreational Trails Program, (formerly the NRTFA), guaranteed annual funding. The program's funding levels increased from $\$ 15$ million to an average of $\$+5$ million annually. Trail advocates should contact their State Trail Coordinator, usually working in the Department of Parks or Natural Resources, for information about project eligibility and their state's application process, selection procedures and funding availability. For information about other changes in this program contact Christopher Douwes at the Federal Highway Administration in Washington, DC: 202-366-5013.

\section{FOR MORE INFORMATION}

$A$ wide range of documents regarding trail funding opportunities under TEA-21 are available from the National Transportation Enhancements Clearinghouse. Call this toll free number: 1-888-388-6832. Some titles include:

- Technical Brief \# 1: De'vcloping a Successful ISTEA Enhancements Application for Trail, Bicycle and Pedestrian Projects.

- Technical Brief \#4: Beyond Enhancements: Making the STP E CMAQ Programs Work for Bicyclists E Pedestrians.

The NTEC also maintains a cumplete set of State Transportation Enhancement Program Profiles (2 pages each), which include state Enhancement Program policies, project funding awards by category, and authorization levels.

As a non-profit public organization, Rails-to-Trails Conservancy is wholly supported by its membership. If you are not already a member, join toduy at one of the following levels: regular (\$18); supporting (\$25); patron (\$50); benefactor (\$100); advocate (\$500); or Trailblazer Society (\$1,000). 